\title{
Teacher and Administrative Staff Views on Teachers' Participation in Decision Making Process
}

\author{
Hasan Eriş ${ }^{1}$, Hatice Kayhan ${ }^{1 *}$, Mert Baştaş ${ }^{2,3}$, Cemal Gamar ${ }^{3}$ \\ ${ }^{1}$ Cyprus International University, Nicosia, N. CYPRUS \\ ${ }^{2}$ Near East Institute, Near East University, Nicosia, N. CYPRUS \\ ${ }^{3}$ Near East University, Nicosia, N. CYPRUS
}

Received 20 September 2017 - Revised 6 October 2017 • Accepted 16 October 2017

\begin{abstract}
The aim of this study is to determine teacher and administrative staff views on, teachers' participation in school related decision-making process who serves in primary schools in Northern Cyprus. In the study, quantitative data were collected and the design of the study was determined as "general screening model." All of the administrators, serving in 2015-2016 school year in Famagusta, were attained (42 administrator), however, only 274 of 392 teachers (69.9\% of the phase) completed the questionnaire. When we look at teacher and administration staff remarks, a significant difference was found in teachers' participation in educational and administrative decisions. This difference was in favour of educational decisions. A significant difference was not met in teacher and administrative staff views on teachers' participation in school related (educational+administrative) decisions considering; gender, age, total working years as teacher, total working years at the school, task type, education level. However, teacher views significantly changed when schools' locations change. This difference was in favour of the teachers working in rural areas. Finally, when participant teachers' and administrators' views were compared, teachers' participation in school related (educational+administrative) decisions shows a meaningful difference. Administrative staff, in comparison to teachers, stated that teachers' participation has to be more in decision making process.
\end{abstract}

Keywords: administration, decision making, teachers' participation in decision making process, North Cyprus education system

\section{INTRODUCTION}

It is emphasised that schools in Turkey and Northern Cyprus are administrated with conventional methods. It is necessary to decrease the negative effects of conventional methods to provide a qualified education. Administrative mentality of schools depend on administrators' requests and profit oriented logic, instead of being teacher, parents, and student oriented. In this case, administrator generally assign duties without consulting to teachers. Administrator does not try to reconcile with the staff and teachers are responsible to fulfil these duties. When teacher do not agreed with the administrator, certain disagreements and conflictual situations are inevitable.

Decision making is one of the important processes of school administration. Schools can be successful as long as they fulfil the needs of its insiders (administration, teachers, servants, students, and parents). Administrators, who accept that schools can be strong with teachers' decision making help, tend to evaluate teachers' any contribution (either educational or administrative) in a positive manner. This approach brings along schools' seek for efficient education system.

Teachers participation in decision making can increase the quality of education. (Lunenburg \& Ornstein, 2011). The approach of participation of people, who affected by the decisions, has been defended by educational administration theoreticians since 1930s. (Lunenburg, 2010) In this approach, there is a belief of superiority of

(C) Authors. Terms and conditions of Creative Commons Attribution 4.0 International (CC BY 4.0) apply.

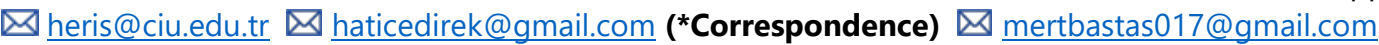
cemalgamar@hotmail.com 


\section{Contribution of this paper to the literature}

- Participation in school's development and innovative decisions of teachers, creates an energetic atmosphere in school and strengthens teamwork.

- In spite of that, it can be said that although teachers are being included in the decision making process but, they are not happy with it and asking for more.

- Teachers need to be "authorized" to participate in decision making process, and to shoulder responsibility of the decisions.

participated decisions which are more valid and has more support behind. Participation play a huge role in comprehension, adaptation, and efficient application of the decision. On the other hand, participation in decision making, helps member's to identify with organizational and individual purposes and programmes (Aksay \& Ural, 2008).

Teachers participate in every single school event at the front lines. That is why, teachers' views are important to make development and exchange programmes to be successful. It is not easy to run a programme without being permitted, accepted or assimilated by a teacher. It is possible to force teachers to fulfil some tasks, however, this could negatively affect their bonds with the organization. It is difficult for a teacher to do beneficial initiatives without the sense of belonging to an organization (school). Balay (2000) and Çetin (2004) emphasized that for teachers: there is a lot of factors which create the organizational sense of belonging and underscored that one of these is the participation in decision making process.

Participation in school's development and innovative decisions of teachers, creates an energetic atmosphere in school and strengthens teamwork. It is also possible to have parents participate in this process which meant parents' participation in decision making. Teacher serves as a bridge between parents and administration, so that they connect, and potential problems can be solved without emerging. Proactive parents and teachers are always in favour of problem solving (Moore et al, 2016) This main problem question below is tried to be searched together with its sub problems: What are the remarks of teachers and administrators, serving in primary schools in Northern Cyprus, Famagusta City, on teachers' participation in school related decision making process?

Sub-problems of the research question:

What are the opinions of teachers and administrators, who serve in primary schools in Northern Cyprus, Famagusta, on teachers' participation in school related decision making process?

a) What is the distribution of educational decisions?

b) What is the distribution of administrative decisions?

c) Do teachers' opinions differ regarding teachers' participation in educational and administrative decisions? Considering following factors;

a. Gender,

b. Age,

c. Total working years as teacher,

d. Total working years at the school,

e. Being branch, and form teacher\& / being headmaster-vice principal,

f. Education level,

g. School's location,

Do teachers' and administrators', views on teachers' participations in school related decision making process, significantly differ?

Regarding teachers' participation in decision making process do teachers', and administrators', serving in primary schools in Northern Cyprus, Famagusta, does these remarks significantly differ from each other?

\section{Literature Review}

School administration is the application of educational administration within a limited area, and can be stated as the unification, and efficient use of each and every materiel and staff, and the application of goal oriented policies and decisions (Demirtaş, 2010). Headmaster administrates the school organization. Headmaster's successful administration depends on his/her fully comprehension of his/her role and other staffs' roles and organizing his/her attitudes regarding these (Çelik, 2009). From this point of view, it is important to dwell on school administrative processes and "decision-making process", which is an important part of these processes. 
The difference that differs school administration from other administration types is that school's output is human-beings. School is where education service is produced, and headmaster occurs everyone's mind when it is said "school administration". Headmaster's decision-making roles are based on three classes: First one is the decisions related to materials within the system, and it is organizational function of the administration. Second one is the decisions based on administration, and directive function of the administration. Third one is surveillance or control functions. Administrators, in a centralist administrative system, are assigned to transmit the tasks from ministry to the subordinates. Because administrators are not highly entitled to decide school related subjects, it is not necessary to have subordinates involved in the administration (Akgül, 2006).

Teachers are the most affected staffs through decisions. Teachers, who take on critical tasks such as; educational strategies to follow, the main attitudes and behaviours that students should have, how to familiarize the school, hot yo have a healthy communication with parents, must participate in decision making process, in person, to fulfil these duties. It is easier for everyone to apply decisions that decided by themselves. This is same for teachers as well. To increase the success of a school, teacher, who actively participate in decision making process, would voluntarily apply these decisions, and would work efficiently to make the school successful (Başyiğit, 2009).

High morale, increase in sense of belonging to school, decrease in absenteeism and leave of employment, increase in decisions' efficiency and quality, high acceptance of change, increase in teamwork and decrease in disagreements, maintaining an efficient discipline, informing teachers more efficiently, increase in teachers intercommunications in school, increase in students' motivations, augmentation of inspiring events in school to keep qualified teachers in school and to attract other teachers, enhancing school's atmosphere, increase in loyalty towards shared decision making, and increase in teachers' and administrators' interrelations, are the positive effects of teachers' participation in decision making process (Aytaç, 2000).

According to Özdemir and Cemaloğlu (2000), teachers, who participate in decision making process, would have increased motivation levels. Participation in decision making can also increase organizational learning environments in schools. Teachers, who participate in decision making process, try to balance their individual goals and organizational goals. Participating in decision making process can cause an individual satisfaction. Teachers, who participate in decision making process, tend to create a more qualified educational environment. Teachers' motivation levels can increase, if they participate in decision making process. This can affect teacher mobility, and a well-balanced, a steady teaching staff can be composed. And this make teachers harder to reach the purpose of decisions, and play the role of the protectors of the decisions. Also they may suffer from unjust behaviour by being unable to participate in decisions and this may cause their organizational commitments to decrease. (Oztug \& Bastas, 2012)

Although teachers play active roles in children's educations, successes, bringing democracy to schools and society, yet they are mostly being deactivated when it comes to school administration, and development of policies that directly influence the education. So teachers become every other day more alienated from school, and try to express themselves through different, external organizations. (Uyar, 2007). Although most of the teachers are invited to take part in trouble shooting, they think that decisions are already made by the headmaster, and it is impossible to change these decisions, so they, on the ground that it is a waste of time, do not want to participate in it. (Özdemir and Cemaloğlu, 2000). Under such circumstance, from the beginning of the decision making process, the headmasters should not try to push his personal intentions and prejudgements on teachers.

Headmasters' teacher authorizations are the key factor of teachers' participations in decision making process. Teachers need to be "authorized" to participate in decision making process, and to shoulder responsibility of the decisions. Authorized teachers believe in what they do and care about it, their activities are in cohesion with their value systems, they are motivated, and energetic. It is obvious that authorized teachers are more progressive and satisfied. To create an authorized teacher environment, headmaster needs to increase the accessibility of school informations, to insist for teachers' participation in decision making process, to encourage class based innovations, and self-rule. (MacTavish \& Kolb, 2006; Rosenblatt, 2007).

Somech and Bogler (2002), have divided teacher participation into two main scope: first one, students and education based scope, (such as; discipline of student, and teaching policy), which is "technical decisions", and school activities, and administrative based scope, (to determine school's purpose, and staff's employment) "administrative decisions". According to Güçlü (2000), teachers participate in decision making by planning, ruling the class, and developing educational programmes. Teachers are authorized to participate in decision making, which affects them directly or indirectly such as, budget allocation, educational programmes, and students' disciplines. Teacher should participate in decision making process concerning; student absenteeism, material selection regarding regional policies, teaching materials and strategies, staff development, and goal planning.

According to Yalın and others (1996), it is mentioned that the participation of teacher is necessary considering such decisions; school administration especially educational programme planning and application, application of educational activities regarding students' educational levels. Aldemir (1996), on the other hand, summarised teacher's participation in decision making as the following: 
- Application of education and training subject

- Staff and Employee personal rights

- Development and regulation of syllabus

- In-service educational activities

- Schools bodily improvements, and purchasing equipments

- Committees and professional actions

\section{METHOD}

Data were collected in accordance with quantitative research, and screening model was determined to describe the existing situation. The design of the study was regulated regarding "general screening model". The study is conducted to indicate the views of teachers and administrators, who serve in primary schools in Northern Cyprus, Famagusta City, on teachers' participation in decision making process, and to describe the current situation with all faults. Independent variable of the study; gender, seniority, age, being branch and form teacher, serving area, educational level, and salary. Dependent variable of the study is, on the other hand, "teachers' participation level of decision making process."

\section{Population and Sample}

The population of the study is teachers and administrators, who serve in primary schools in Northern Cyprus, Famagusta city, during the 2015-2016 school year. By the school year 2015-2016, there are 32 public and 1 private primary schools in Famagusta city; in total 392 teachers are serving. 112 of these teachers are males and 280 of these teachers are females. As part of the study it is intended to reach the population, which is each and every administrator (headmasters and vice-principals) and teacher, who serve in primary schools in Famagusta, and samples were taken. However, some of the applicants did not complete the questionnaires. At a private educational institution, it was not permitted teachers to complete the questionnaires (despite the permission from the Ministry of National Education.).

42 participant administrators' characteristics are as the following: 40.5\% (17) of the participant administrators are female and $59.5 \%(25)$ of them are male. $6(14.3 \%)$ of the administrators are in the age range of $31-40,23(54.8 \%)$ of them are in the age range of $41-50$, and $13(31.0 \%)$ of them are aged 51 and older. $4(12.0 \%)$ participant administrators have been serving as teachers for 11-15 years, 11 (17.2\%) of them have been serving for 16-20 years, and $27(15.0 \%)$ of them have been serving for 21 years and more. Regarding their service in administration, 12 $(28.6 \%)$ of them have been serving for 1 year and less, $6(14.5 \%)$ of them have been serving for $2-4$ years and 24 $(57.1 \%)$ of them have been serving for 5 years and more. It was identified that $27(64.3 \%)$ of the administrators are headmasters, and 15 (35.7\%) of them are vice-principals; it was also identified that 25 (59.5\%) of them are serving in rural areas (villages of Famagusta), and 17 (40.5\%) of them are serving in urban area (in Famagusta). It was stated that $39(92.9 \%)$ of them have bachelor degree, and $3(7.1 \%)$ of them have master's degree.

274 participant teachers' characteristics are as the following: 70.4\% (193) female teachers and 29.6\% (81) male teachers participated in our study. It was specified that $113(41.2 \%)$ of the participant teachers are at the age range of $21-30,91(33.2 \%)$ of them are at the age range of 31-40, $60(21.9)$ of them are at the age range of 41-50, and 10 $(3.6 \%)$ of them are aged 51 and older. Professional seniority of $96(35.0 \%)$ of participant teachers is in between 1-5 years, professional seniority of 57 of them $(20.8 \%)$ is in between $6-10$, professional seniority of $33(12.0 \%)$ of them is 11-15 years, professional seniority of $47(17.2 \%)$ of them is 16-20, and professional seniority of $41(15.0 \%)$ of them is 21 years and more. Regarding participant teachers' duration at their schools of duty, 64 (23.4\%) of them have been serving at the same school for one year or less, 64 of them $(23.4 \%)$ of them have been serving at the same school for 2-4 years, $146(53.3 \%)$ of them have been serving at the same school for 5 years or more, it was also mentioned that $185(67.5 \%)$ of them are form teachers and $89(32.5 \%)$ of them are branch teachers. It was stated that $244(89.1 \%)$ of them have bachelor degree and $30(10.9 \%)$ of them have master's degree; $168(61.3 \%)$ of them are serving in rural areas (villages of Famagusta) and 106 (38.7\%) of them are serving in urban area (in Famagusta).

\section{Data Collection Tool}

As part of the study Başyiğit's (2009) "Participation in Decision Scale" was used. As part of the questionnaire, teachers' levels of participation in decision making was scrutinised under two scopes; "education-training (technical)" and "administrative decisions". The questionnaire was composed of 26 articles regarding 5 point likert scale. The answers of the questionnaire was organised to be graded as; "never 1", "rarely 2", "sometimes 3", "usually 4", and "always 5". When examining the reliability of sub-dimensions of the questionnaire, the reliability of the sub-dimension of education-training (technical decisions) was stated as 0.94; the reliability of the subdimension of administrative decisions was stated as 0.92 . The cronbach's alpha reliability coefficient of the 
Table 1. Total Score Interval of Likert Scale

\begin{tabular}{ccc}
\hline Option & Option Score & Option Score Interval \\
\hline Never & 1 & $1.00-1.79$ \\
\hline Rarely & 2 & $1.80-2.59$ \\
\hline Sometimes & 3 & $2.60-3.39$ \\
\hline Usually & 4 & $3.40-4.19$ \\
\hline Always & 5 & $4.20-5.00$ \\
\hline
\end{tabular}

questionnaire is, on the other hand, 0.95. As part of the scale development process, Varimax factor analysis was conducted. When examining explained total variance, it can be said that 26 articles were gathered under 2 factors, and $53 \%$ of evaluated characteristic through 2 -factor evaluation tool, was stated. As a result of the factor analysis, articles', which converted to factors, factorial load points were also evaluated. 0.45 or higher factorial load point is a good measurement for an article. Factorial load point of each factor in the scale was measured higher than 0.45.

\section{Data Collection}

The scale, used in the study, was approved by the department of instruction and education and the department of primary education of Ministry of National Education of Northern Cyprus. The researcher reached the schools (participants), as part of the research, in person, with the approbation, within school working our, explaining necessary matters of the scale, and expected participants voluntarily answer the questionnaires. The total number of scales that are answered by the participant teachers is $316(73 \%)$.

\section{Data Analysis}

Collected data, through scales, were computerised, and analysed by the researchers via SSPS 15.0 for Windows packaged software. The significance level, as part of the study, was recorded as $\mathrm{p}<0.05$.

Percentage, frequency, arithmetic average, standard deviation methods were used concerning each and every statement, to evaluate teachers' and administrators' views on teachers' participation in school related decision making process. The score interval of the questionnaire, enhanced as 5 point likert scale is stated in Table 1.

An independent $t$-test was conducted to determine if the variance of gender, location of school, education level, being branch or form teacher, being headmaster or vice-principal cause any significant change regarding teachers' and administrators' views on teachers' participation in decision making process. A dependent t-test, on the other hand, was conducted to see under which sub-dimension (educational, or administrative?) teachers' and administrators' views on their participation in decision making process, concentrate.

ANOVA was used to see if the variance of total working years as teacher, total years of working at the school, and age did cause any significant change in the views of teachers' and administrators' on teachers' participation in decision making process.

Finally, an independent $t$-test was conducted to determine if participant teachers' and administrators' views on teachers' participation in decision making process significantly differ from each other.

\section{FINDINGS}

\section{What is the Distribution of Teachers' Remarks on Teachers' Participation in Educational Decision Making Process?}

Arithmetic average of teachers' views on teachers' participation in educational decision making process resulted usually option $(\bar{X}=3.52)$. Arithmetic average of teachers' responses, there are 8 articles that are equal to "Usually" score interval (3.40-4.19). Arithmetic average of teachers' responses, there are 6 equal articles to "Sometimes" score interval (2.60-3.39). The article that resulted the highest average is "I participate in decision making process of school's social activities" $(\bar{X}=4.02 \pm .82)$. The article that resulted the lowest average is "I participate in decision making process of school's library regulations" $(\bar{X}=3.09 \pm 1.24)$.

\section{What is the Distribution of Teachers' Remarks on Teachers' Participation in Administrative Decision Making Process?}

The arithmetic average of teacher views on teachers' participation in administrative decision making process resulted sometime $(\bar{X}=3.19)$ option. There are 4 articles that are equal to "Usually" (3.40-4.19) option, 6 articles equal to "Sometimes" (2.60-3.39) option, and 2 articles equal to "Rarely" (1.80-2.59) option of the arithmetic average of 
Table 2. The Comparison of Teacher Views on Teachers' Participation in Administrative Decision-making Process

\begin{tabular}{ccccccc}
\hline Participation in Decision-making & $\mathbf{N}$ & $\overline{\boldsymbol{X}}$ & $\mathbf{S}$ & $\mathbf{s d}$ & $\mathbf{t}$ & $\mathbf{P}$ \\
\hline Educational & 274 & 3.51 & 0.8 & 273 & 1.34 &, 000 \\
\hline Administrative & 274 & 3.19 & 0.9 & & & \\
\hline
\end{tabular}

Table 3. The Comparison of Teacher Views on Teachers' Participation in Decision-making Process Regarding School Location Factor

\begin{tabular}{ccccccc}
\hline & $\boldsymbol{N}$ & $\overline{\boldsymbol{X}}$ & $\boldsymbol{S S}$ & $\boldsymbol{t}$ & $\boldsymbol{S d}$ & \\
\hline Rural & 168 & 3.47 & 0.8 & 2,921 & 272 & .004 \\
\hline Urban & 106 & 3.18 & 0.8 & & & \\
\hline
\end{tabular}

teachers' responses. The article that resulted the highest average is "I participate in decision making process of school building and student security" $(\bar{X}=3.77 \pm 0.93)$, whereas, the lowest average is "I participate in decision making process of determining school income, and expenses" $(\bar{X}=2.40 \pm 1.23)$.

\section{Do Teachers' Opinions Differ Regarding Teachers' Participation in Educational and Administrative Decisions?}

Base on dependent $t$-test results, according to teacher views, the average of teachers' participation in educational statement during the process of decision making resulted $(\bar{X}=3.51 \pm .80)$ higher than administrative statements $(\bar{X}=3.19 \pm .90)(\mathrm{t}=1.34, \mathrm{p}<.05)$.

When examining teacher views on their own participation in school related decision making process, teacher views who serve in rural areas average value is $(\bar{X}=3.47, \pm .80)$, and teacher views who serve in urban areas average value is $(\bar{X}=3.18, \pm .80)$. It was mentioned that teachers who serve in rural areas participate in decision making process more than teachers in urban areas $(\mathrm{t}=2.921, \mathrm{p}<0.05)$.

\section{What is the Distribution of Administrator Views on Teachers' Participation in Educational Decisions?}

Administrator views on teachers' participation in educational decisions' arithmetic average was resulted always option $(\bar{X}=4.43)$. There are 12 articles that are equal to the arithmetic average of administrators' responses' "Always" score interval (4.20-5.00). There are 2 articles that are equal to the arithmetic average of administrators' responses' "Usually" score interval (3.40-4.19). The article that resulted the highest average is "I include my fellow teachers in decision making process of avoiding student absenteeism." $(\bar{X}=4.66 \pm .47)$. The article that resulted the lowest average, on the other hand, is "I include my fellow teachers in decision making process of cooperating with other organizations." $(\bar{X}=4.11 \pm .80)$.

\section{What is the Distribution of Administrator Views on Teachers' Participation in Administrative Decisions?}

The arithmetic average of administrators' views on teachers' participation in administrative decision making process was resulted always option $(\bar{X}=4.25)$. There are 9 articles that are equal to administrators' responses' arithmetic average "Always" score interval (4.20-5.00). There are 3 articles that are equal to administrators' responses' arithmetic average "Usually" score interval (3.40-4.19). The article that resulted the highest average is "I include my fellow teachers in the decision making process of classroom and other sections equipping. $(\bar{X}=4.59 \pm$ .49). The article that resulted the lowest rate, on the other hand, is "I include my fellow teachers in the decision making process of purchasing." $(\bar{X}=3.52 \pm .96)$.

\section{Do Administrators' Views on Teachers' Participation in Educational and Administrative Decision Making Process Differ from One to Another?}

According to the results of dependent t-test, it is mentioned that administrators include teachers mostly in educational decisions $(\mathrm{t}=0.88, \mathrm{p}<0.05)$. 
Table 4. The Comparison of Teachers Participation in Decision-making Process Regarding Administrator Views

\begin{tabular}{ccccccc}
\hline Participation in Decision-making & $\mathbf{N}$ & $\overline{\boldsymbol{X}}$ & $\mathbf{S}$ & $\mathbf{s d}$ & $\mathbf{t}$ & $\mathbf{p}$ \\
\hline Educational & 42 & 4.43 & 0.39 & 273 & 0.88 &, 000 \\
\hline Administrative & 42 & 4.25 & 0.48 & & & \\
\hline
\end{tabular}

Table 5. The Comparison of Teacher and Administrator Views on Teachers' Participation in Scchool Related Decision-making Process

\begin{tabular}{ccccccc}
\hline Participation in Decision-making & $\mathbf{N}$ & $\overline{\boldsymbol{X}}$ & $\mathbf{S}$ & $\mathbf{s d}$ & $\mathbf{t}$ & $\mathbf{p}$ \\
\hline Teacher & 274 & 3.36 & 0.79 & 313 & -0.394 &, 000 \\
\hline Administrator & 42 & 4.35 & 0.40 & & & \\
\hline
\end{tabular}

\section{Do Administrators' Remarks on Teacher's Participation in School Related Decision Making Process, Significantly Differ Considering Following Factors; Gender, Age, Total Working Years as Teacher, Total Working Years at the School, Education Levels, Being Headmaster, or Vice-Principal, School Location?}

According to independent t-test results, administrator views on teachers' participation in school related (educational+administrative) decision making process a significant difference was not found considering the factors of "gender", "age", "total working years", "total working years at the school", "duty type", "education level", and "school location" ( $p>0.05)$.

\section{Regarding Teachers' Participation in Decision Making Process do Teachers', and Administrators', Serving in Primary Schools in Northern Cyprus, Famagusta, Remarks Significantly Differ from Each Other?}

A significant difference was observed, when comparing administrator views with teacher views regarding independent $\mathrm{t}$-test results $(\mathrm{t}=-0.394, \mathrm{p}<0.05)$. Administrators indicated that they include teachers in school related decision-making.

\section{CONCLUSION AND SUGGESTIONS}

According to research results of Açıkgöz (1984), Köklü (1994), Bilgin (1996), Gürkan (2006), and Özcan (2010), teacher views on their participation in decision making process gathered under the option of "very little". Yavuz (2001), on the other hand, found in his research that lycée teachers' views on participation in decision-making, found as "little" level ( $\bar{X}=2.47)$. Whereas, according to Uygun's (2004) research results, primary school teachers believe that their headmasters' participative administration approach is "highly sufficient" and "sufficient". However, Giray (2006) indicated some limitations which were highly effective over the "highly sufficient" and "sufficient" results of Uygun's research (2006) such as; the headmaster was the researcher, and handed out the questionnaires, and participants thought that the headmaster knew about them.

According to Mete's research results (2004) and Goldring et.al (2015) teachers believe that administrators do not include teachers in decision making process. Regarding Özden's research (1996) teachers revealed that their opinions on various subjects rarely asked, and indicated that administrators make decisions between each other, and perfunctorily ask teachers' opinions. According to teacher views in Kaya's study (2000), administrators who have the formation of administration adopt a more democratic attitude in decision making process, include school staff more frequent, in decision making process in the purpose of troubleshooting, distribute his/her responsibilities and authorities more equally, and finally when making a decision s/he assigns some of her/his authorities to subordinates, in comparison with administrators without the formation of administration. According to Barut's research (2007) on the other hand, administrators, who were assigned through an examination, found more efficient in term of including teachers, who affected by the decisions the most, more sufficiently in decision making process.

Most of the studies emphasised that teachers participate more in educational (in comparison with administrative decisions) decision making process (Açıkgöz, 1984; Akgül, 2006; Aksay ve Ural, 2008; Gürkan, 2006; Köklü, 1994; Özcan, 2010). The result of this study is promoting studies mentioned above.

According to teacher views in the researches of Akgül (2006), Aksay ve Ural (2008), Aldemir (1996), Karaca (2001), Özcan (2010), and Uyar (2007), the gender factor did not cause any significant difference. The results of literature coincide with the findings of this research. On the other side, according to Köklü's research (1994) male teachers participate more in decision making process than female teachers. Similarly in Yildiz's research (1998) 
male teachers' participation rate in decision making was found higher than female teachers' participation rate. According to Yavuz (2001) and Gürkan's (2006) researches, on the other hand, female teachers participate more in decision making process than male teachers.

According to Akgül's (2006) research, the age factor did not cause any significant change in teacher views who serve in public and private primary schools. In this research a significant change did not found regarding age factor as well.

Teacher views did not significantly differ, in most of the studies (Aksay \& Ural, 2008; Gürkan, 2006; Köklü, 1994; Özcan, 2010; Y1lmaz, 2005), regarding the factor of being branch or form teachers. The result of this study is similar with the studies mentioned above. On the other hand, as part of Başyiğit's research, branch teachers' level of participation in decision making was found higher than form teachers' participation levels.

According to the researches of Uyar (2007), Başyiğit (2009), and Takmaz \& Yavuz (2010), teachers', who serve in primary schools, views on teachers participation in educational and administrative decision making process did not differ regarding education level factor. The same result was found in this research.

According to this research, considering the variant factors, teacher views on teachers' participation in school related decision making process, differed only when regarding the school location factor. Teachers, who serve in rural areas (villages of Famagusta) stated that they participate in decision making process more than those serve in city centre. The raison of this is because, schools in rural areas are smaller with more intimate relations. It is also thought that schools in rural areas competing less than those in urban areas.

When regarding administrator views on teachers' participation in school related decision making process, Yavuz's (2001) study is remarkable. According to the findings of Yavuz's research (2001), the state of including and the intention of including significantly differ. School administrators stated that teacher participation in decision making is mid-level, however, they want to include teacher more than that in the process. According to Köklü's (1994) study, headmasters believe that teachers are not sufficient in terms of efficient decision making. Headmasters want teachers to participate more in educational decisions than administrative decisions, and think that teachers are more sufficient for educational matters. For Özdemir et.al (2016) it is crucial for decision makers to consider participants' statements for the effectiveness and success of change.

According to Yavuz's research (2001) administrator views on the state of including teachers in decision making, and intention of including did not differ significantly, considering gender factor. The result of this study coincides with the result of Yavuz's research. Similarly, administrator views, considering the total working years factor, on teachers' participation in school related decision making process, did not differ significantly. The result of this study coincides with Yavuz's (2001) finding. According to Uyar's study (2007), on the other side, administrator views on teacher's participation in administration, did not cause a significant difference regarding education level (bachelor, masters degree.) A similar result was found in this research as well. Differing from the variance factors above, according to Yavuz's research (2001), administrator views on teachers' participation in decision making differed, regarding administrators' total year of service. The group, that serves at the administration for 1-5 years (in comparison with the group of 6-10 years), stated that they include teachers less in decision making process.

Administrators' intention of including teacher in decision making process differs from teachers' intention of participating in the process of decision-making. Results by Duke, Showers and Imber (1980) states that the teachers interviewed rated the potential costs of decision making involvement as low and the potential benefits as high. Nevertheless, many were hesitant to become involved because they saw little possibility that their involvement would actually make a difference. Regarding this, administrators want to include teachers in the decision making process as much as teachers unwillingness, this should be examined. Perhaps, administrators want to include teachers in the process because they are in need of sharing their responsibilities, or fulfilling their lack of administrative skills. Another approach is that administrators are economical with the truth of including teachers in the process of decision-making. In spite of that, it can be said that although teachers are being included in the decision making process but, they are not content with it and asking for more.

Lastly, teacher and administrator views in favour of including teachers more in educational decision-making (in comparison with administrative decision-making) can be analysed by qualitative research questions as well. As it is stated in the literature, the reasons of teacher and administrator views' differences on teachers' participation in decision-making process can further be investigated through qualitative research questions.

\section{REFERENCES}

Açıkgöz, K. (1984). Öğretmenlerin okuldaki kararlara katılımı (Unpublished Doctoral Thesis). Ankara: Hacettepe Üniversitesi, Sosyal Bilimler Enstitüsü.

Akgül, M. (2006). Ankara merkez ilçeleri resmi-özel beden eğitimi öğretmenlerinin ilköğretim okullarında alınan kararlara katılımı. Ankara: Ankara Üniversitesi, Sağlık Bilimleri Enstitüsü. 
Aksay, O., \& Ural, A. (2008). Ortaöğretim öğretmenlerin okulla ilgili kararlara katılımı. Türk Ĕ̆itim Bilimleri Dergisi, 6(3), 433-460.

Aldemir, G. (1996). Öğretmenlerin okul yönetimine katılım düzeyleri (Altındağ örneği) (Unpublished Masters Thesis). Ankara: Gazi Üniversitesi, Eğitim Bilimleri Enstitüsü.

Aytaç, T. (2000). Okul Merkezli Yönetim. Ankara: Nobel Yayın Dağıtım.

Balay, R. (2000). Özel ve resmî liselerde yönetici ve öğretmenlerin örgütsel bağhllğ̆l (Unpublished Doctoral Thesis). Ankara: Ankara Üniversitesi, Sosyal Bilimler Enstitüsü.

Barut, E. (2007). İlköğretim okullarında sınavla atanan yöneticilerle sınavsız atanan yöneticilerin yönetme süreçlerine ilişkin yeterliliklerinin değerlendirilmesi: Sakarya ili örneği (Unpublished Masters Thesis). Sakarya: Sakarya Üniversitesi, Sosyal Bilimler Enstitüsü.

Başyiğit, F. (2009). Öğretmenlerin karar alma sürecine katılım düzeylerinin örgütsel bağhllk düzeyleri ile ilişkisi (Unpublished Masters Thesis). Ankara: Gazi Üniversitesi, Eğitim Bilimleri Enstitüsü.

Bilgin, T. F. (1996). Zonguldak merkez ilköğretim okullarındaki öğretmenlerin okul yönetimlerince alınan kararlara katılabilme derecelerinin değerlendirilmesi (Unpublished Masters Thesis). Ankara: Gazi Üniversitesi, Eğitim Bilimleri Enstitüsü.

Çelik, V. (2009). Türk Ĕ̆itim Sistemi ve Okul Yönetimi. 2. Baskı, Ankara: PegemA Yayıncılık.

Çetin, M.Ö. (2004). Örgütsel Vatandaşlık Davranışı. Ankara: Nobel Yayın Dağıtım.

Demirtaş, H. (2010). Okul örgütü ve yönetimi. Türk Ĕ̆itim Sistemi ve Okul Yönetimi, (Editör, R. Sarpkaya), 2. Baskı. Ankara: Anı Yayıncilik.

Duke, D. L., Showers, B. K., \& Imber, M. (1980). Teachers and shared decision making: The costs and benefits of involvement. Educational Administration Quarterly, 16(1), 93-106.

Giray, N. (2006). Okul yöneticilerinin yönetimsel karar verme/problem çözme yeterliliği (Unpublished Masters Thesis). İstanbul: Yeditepe Üniversitesi, Sosyal Bilimler Enstitüsü.

Goldring, E., Grissom, J. A., Rubin, M., Neumerski, C. M., Cannata, M., Drake, T., \& Schuermann, P. (2015). Make room value added: Principals' human capital decisions and the emergence of teacher observation data. Educational Researcher, 44(2), 96-104. doi:10.3102/0013189X15575031

Güçlü, N. (2000). Okula dayalı yönetim. Milli Ĕ̆itim Dergisi, 148, 23-29.

Gürkan, M. (2006). Mesleki ve teknik eğitim kurumlarında görev yapan öğretmenlerin karara katılım durumları (Unpublished Masters Thesis). İstanbul: Yıldız Teknik Üniversitesi, Sosyal Bilimler Enstitüsü.

Karaca, N. (2001). İlköğretim okullarında öğretmenlerin karara katılma düzeyleri (Unpublished Masters Thesis). Ankara: Gazi Üniversitesi, Eğitim Bilimleri Enstitüsü.

Kaya, A. (2000). İlköğretim okullarında görev yapan eğitim yöneticilerinin yönetim süreçlerinde gösterdikleri yönetsel işlevlerin değerlendirilmesi (Gaziantep ili örneği) (Unpublished Masters Thesis). Gaziantep: Gaziantep Üniversitesi, Sosyal Bilimler Enstitüsü.

Köklü, M. (1994). Ortaöğretim okullarında öğretmenlerin kararlara katılımı (Unpublished Doctoral Thesis). Malatya: İnönü Üniversitesi.

Lunenburg, F. C., \& Ornstein, A. C. (2011). Educational administration: Concepts and practices. Boston: Cengage Learning.

Lunenburg, F. C. (2010). The Decision Making Process. In National Forum of Educational Administration E Supervision Journal, 27(4).

MacTavish, M. D., \& Kolb, J. A. (2006). Encouraging teacher engagement: A new approach to performance improvement in schools. Pennsylvania State University: ERIC.

Mete, A. (2004). İlköğretim okullarında öğretmenlerin güçlendirilmesi. XIII. Ulusal Eğitim Bilimleri Kurultayı, Malatya: İnönü Üniversitesi, Eğitim Fakültesi.

Moore, K. J., Garbacz, S. A., Gau, J. M., Dishion, T. J., Brown, K. L., Stormshak, E. A., \& Seeley, J. R. (2016). Proactive parent engagement in public schools: Using a brief strengths and needs assessment in a multiple-gating risk management strategy. Journal of positive behavior interventions, 18(4), 230-240. doi:10.1177/1098300716632590

Özcan, E. G. (2010). Ortä̈ğretim okullarındaki ögrretmen ve öğrencilerin okul yönetiminin karar verme sürecine katılımlarının incelenmesi (Beypazarı örneği) (Unpublished Masters Thesis). Ankara: Gazi Üniversitesi, Eğitim Bilimleri Enstitüsü.

Özdemir, S., \& Cemaloğlu, N. (2000). Eğitimde örgütsel yenileşme ve karara katılma. Milli Eğitim Dergisi, 146. Retrieved on 12 November 2011 from http:/ /yayim.meb.gov.tr/dergiler/146/ozdemir.htm 
Özdemir, T. Y., Karakose, T., Uygun, H., \& Yirci, R. (2016). Educational Employees' Perceptions Regarding Changes in Educational Organizations. Revista de Cercetare si Interventie Sociala, 53, 288.

Özden, Y. (1996). Okullarda katılmalı yönetim. Eğitim Yönetimi, 2-3, 427-438.

Oztug, O., \& Bastas, M. (2012). The Effects of Teachers' organizational Justice Perceptions On Organizational Commitment. Hacettepe Universitesi Egitim Fakultesi Dergisi-Hacettepe University Journal of Education, 125-133.

Rosenblat, Z. (2007). Teacher involvement in change: A cross-cultural study of principals' and teachers' perspectives. Paper for presentation at The Annual Meeting of the American Educational Research Association. April 8-12, Chicago.

Somech, A., \& Bogler, R. (2002). Antecedents and consequences of teacher organizational and professional commitment. Educational Administration Quarterly, 38(4), 555-577.

Takmaz, Ş., \& Yavuz, M. (2010). İlköğretim okullarında örgütsel iletişim düzeyi ile öğretmenlerin karara katılma davranışlarının analizi. Selçuk Üniversitesi Ahmet Keleşoğlu Eğitim Fakültesi Dergisi, 29, 1-18.

Uyar, Ş. (2007). Öğretmen ve yöneticilerin görüşlerine göre öğretmenlerin okul yönetimine katılmaları (Düzce ili örneği) (Unpublished Masters Thesis). Ankara: Ankara Üniversitesi, Eğitim Bilimleri Enstitüsü.

Uygun, T. (2004). İlköğretim okulu müdürlerinin katılımcı yönetim yeterlilikleri (Çanakkale örneği). Milli Ĕ̆itim Dergisi, 162. Retrieved on 25 December 2011 from http:/ /yayim.meb.gov.tr/dergiler/162/uygun.htm

Yalın, H. İ., Hedgess, L., \& Özdemir, S. (1996). Her Yönüyle Öğretmen Olabilme. Ankara: Milli Eğitim Basımevi.

Yavuz, Y. (2001). Lise yöneticilerinin ve öğretmenlerinin okulda yerinden yönetim ve merkezden yönetim yaklaşımlarına ilişkin görüşlerinin karar verme sürecine etkileri (Unpublished Doctoral Thesis). İzmir: Dokuz Eylül Üniversitesi, Eğitim Bilimleri Enstitüsü.

Yıldız, İ. (1998). İlköğretim okulu öğretmenlerinin okul yönetimindeki karar verme sürecine katılım düzeyleri (Unpublished Masters Thesis). Çanakkale: 18 Mart Üniversitesi, Sosyal Bilimler Enstitüsü.

Yılmaz, N. (2005). İlköğretim kurumlarında görev yapan öğretmenlerin okul yönetimine katılma düzeyleri (Ankara ili örneği) (Unpublished Masters Thesis). Ankara: Gazi Üniversitesi, Eğitim Bilimleri Enstitüsü.

\section{http://www.ejmste.com}

